\title{
Problems and Countermeasures on the Early Stage Property Management in Urban Residential District
}

\author{
Zhongxiang Yuan \\ School of Civil Engineering \& Architecture of Linyi University, Linyi, Shandong, China \\ yuanzhongxiang@lyu.edu.cn
}

Keywords: Residential district; Early stage property; Property; Management; Strategy

\begin{abstract}
It is special in early stage property management in urban residential district. Many disputes in real life are concentrated in the early stage of the property management. So the problems in the management of property management should be carefully studied. It is very important to enhance the early stage property management, protect the legitimate rights and interests of the parties, reduce the contradictions and disputes in the property management, and enhance the transparency of property management, and strengthen the management of property.
\end{abstract}

\section{Introduction}

Due to rolling development of the property projects, the occupancy of homeowners is a gradual process. During the process, especially in the process of construction, it needs early intervention in property management.

\section{The Location of Early Property Management in Urban Residential District}

The Ministry of Construction promulgated Interim Measures for the administration of bid invitation and tendering for the early stage property management. In the second term it clearly pointed that early property management was a property management which an enterprise was hired in charge of the residential district by construction units, before the owners hire an enterprise to manage the property in the residential district. It accurately defines the concept of early property management. It locates the responsibility of the early stage property management in a property management implemented by the construction units who selected property management enterprises [1].

\section{The Characteristics of Early Stage Property Management in Urban Residential District}

Acceptance of Property is the Basis of the Early Stage Property Management. When property companies accept the district, the safety of the body structure and its using functions should be reexamined, which is essential for the implementation of property management and prerequisite conditions. It should be strictly checked on the common parts of the property including public facilities and equipment; especially in it is important to distinguish the responsibility of product quality, construction and installation quality, management and maintenance, so as to ensure the legitimate rights and interests of developers, property owners and property companies.

An Amount of Resources should be Received. There are a large number of data in early stage property management. In order to better carry out property management, the property management company must pay attention to collect, keep and preserve all kinds of information. For example, the details of public parts of the facilities and equipment, various pipelines and underground drainage system drawings, the problems of data rectification reflected by property owners, should be timely collected and classified and filed, in order to be tracked and checked.

Involving Three Parties and with Complex Legal Relationship. The twenty-fifth item in the property management regulations prescribes that the purchasing contract signed between construction units and property buyers should include the contents appointed in the contract agreement. Therefore, this stage involves three parties including the construction units, the property company and the owners. In housing transactions, construction units and the owners are the sale 
relationship. When construction units hire the property management companies, they are a contract relationship. The construction unit chooses a property as the agent of the property owner $\mathrm{s}$ and in the same time, they form a principal-agent relationship between the owners and the construction unit. When the property management company provides service for the owners, they also form a contract relationship [2].

\section{Problems of Early Stage Property Management in Urban Residential Districts}

Lack of Standards in the Contract of Early Stage Property Management. The responsibilities of construction unit and property management companies are not clear. The $21^{\text {st }}$ item in Property management regulations stipulated that before the owners hire property management companies, a early stage service contract engaged in property management enterprises should be written into the contract when construction units hire a property company [3]. In reality, some construction units and property management companies signed the service contract, but they didn't serve the owners according to the regulated contact. This made the core contents of the contract (i.e. the rights and obligations of both parties and the liability for breach of contract) not explicitly written into the contract. It results in the conflict between the two sides, influences the property management, and damages the owners the interests.

Bidding in Property Management of Urban Residential Area is not Standardized. At present, because many districts are not aware of the importance of implementing the bid system, the bidding is still not the main way to hire a property management enterprise. Some developers and property management companies are the relationship of father and son, so usually it is still negotiated by the developers and property management companies in choosing the property company. Some bidding party makes a false bidding though they have designated targets. This makes bidding a form with an amount of bidding cost, waste of resources. Some bidding owners only emphasize on the lowest price, which causes the bidding enterprises competing low prices [4]. Because the developer has not the personnel responsible for bidding, as well as not familiar with the legal system and the work flow of the tender, which causes the property tender not standardized.

\section{Temporary Administrative Statute not Established or not Agreed}

In the sales process, some developers mainly pursue housing sales, ignoring the establishment of Temporary Management Statute. Some developers have developed a temporary management statute, but the terms are simple, the text is not standardized. The responsibilities of two sides are not written into the contract, which will make the legitimate rights and interests of both parties can not only be effectively protected, but be left a legacy for the early property management [5].

Property Acceptance System is not Perfect, the Transfer is not Complete. During the early property management, some property companies belong to real estate developer usually can't strictly undertake the acceptance of the property according to the normal regulations, only because lack of separation in function between construction and management of the property. Some property management companies aim to expand the scale. They usually do things carelessly, which results in its incomplete rules of accepting the property, and the transfer is not complete. Meanwhile it brings a lot of property conflicts, such as the quality of housing and public facilities. The owners concentrate all the contradictions on the Property Management Company, which makes the property management companies a scapegoat [6].

Property Service is not Fit for the Charges. The fifth item in property service charges promulgated by National Development and Reform Commission prescribes that the property management charges should follow the principle of reasonable, open and the cost fit for service level. This principle is that the quality must applicable to the price [7]. However, the mechanism applicable to current property management service charges has not been fully established. Especially in the early stage property management activities, some non-standard property management enterprises take unfair competition, and bargain with each other in order to obtain the right of property management. Some owners do not concern the quality of property services, only 
pursue the lowest price, which the quality can not match the service of the early stage property management. It violates the basic principles of the property service charge.

\section{Countermeasures and Suggestions in Strengthening and Improving the Early Stage Property Management in Urban Residential Area}

Improve the Cognition of the Early Stage Property Management. Property enterprises should put the interests of the owners in the first place, realize the importance of early property management. Meanwhile they should know that the early property management is just like a probation period for hire. Only good quality can keep them stay and renew the property management services contract [3]. The early stage property companies should pay attention to the abilities and quality of the staff in all aspects. The staff in the early stage property management represents the interests of various aspects of the enterprise, so the enterprise should take the consideration of arranging personnel from the perspective of responsibility, ability and ideological awareness, etc.

Regulate the Bidding Behavior of Property Management in Urban Residential Area. The bidding of property management has a significant influence in many aspects, including assuring the publicity of property developers' behavior, maintaining the right of owners to hire property management companies, promoting the separation of real property development and management, promoting fair competition in the property management market, and improving the overall level of property management [4]. The following measures can be taken to stipulate the bidding of early stage property management, including strengthening learning property management bidding system in order for the construction units and property management companies to establish a fair and open bidding competition market; establishing a sound bidding system; establishing and improving arbitration institutions of the property management. Finally, the government departments should conscientiously guide and monitor the bidding in the early stage of property management [8].

Regulate the Property Management Contract, and Strengthen the Supervision on the Leading Position of Construction Units. The early stage service contract is the only legal document of the right and obligation of the property management. Regulating the contract can not only help the connection of construction and management, prevent the disjoint or ignorance of management, but to protect the legitimate rights and interests of the owners, and provide effective basis for the future treatment of disputes. In order to specify the early stage property services contracts, the following measures should be taken. First, the construction unit and hiring property management companies should sign a written contract. Secondly, contract elements including service quality, service fees, rights and obligations of both parties and the default liability should be clearly defined. Thirdly, the property services contract signed between the two parties should maintain the interests, as far as possible in terms of both reasonable and legitimate. Finally, it should be as possible to refine the liability for breach of contract terms, and make a clear agreement on liability for it.

Develop and Improve the Temporary Management Statute. Implementing the temporary management of the statute system can help to improve the owner's sense of self-discipline, prevent and reduce the early property management disputes [9]. When construction units make the temporary management regulations, they must be in accordance with the provisions of the regulations. As standardized as possible, the provisions should not infringe upon the lawful rights and interests of the property owners. The temporary management agreement developed by construction units should be made in accordance with the law, such as the use, maintenance and management of the property. The owners should obey the temporary management regulations and promise in written words.

Further Standardize Acceptance System of the Property. Property service enterprises will formally take over the property from the construction units through the acceptance of the property and take property management. It determines the quality of entire property management in the future to a certain extent. In order to solve the acceptance problems of property management, the key is to establish property management acceptance system, clarifying the responsibilities of 
property services business. Only all the owners participate in management can it effectively solve the problems?

Property Service Enterprises should amend the Concept for the Owners, Provide Them with Patient and Meticulous Service. During managing the property in city residential area, the property service enterprises should be for the sake of the owners. Some behaviors which would damage the interests of owners should be resolutely resisted, such as construction without planned, shoddy work, etc. Many contradictions and problems after the owners live in will be found out in a short time. The employees in property service enterprise should improve their management level, and serve the owners with patience, carefulness and determination sincerely for the owners to solve problems, win the trust of the owners, and lay the foundation for later management.

\section{Summary}

The quality of property management directly relates to people's living quality, the value of housing, stability and harmony in the community. At the same time, it can create a lot of jobs opportunities [10]. Research and analysis of property management status in urban residential area will help to fully understand the existing problems in the current management activities, promote the development of property management and real estate development, ensure the healthy development of the property management industry, and effectively reduce the conflicts of property management. At the same time it has a certain role in speeding up the process of property management market, changing the awareness of the property service enterprise and improving service quality, enhancing the public awareness of the owners, and improving the entire attention of the whole society.

\section{References}

[1] Yang hong. Discuss on Common Problems and Countermeasures of Preliminary Property Management. Value Engineering. 2010(12) pp. 152.

[2] Fu Jing. The Problems and Countermeasures on early intervention of Our Property Management. Manager Journal, 2014(13) pp. 85

[3] Yin Guang-ming. Small area in front of the Property Management mediator into research. China Economist, 2013. (4) pp. 277-279.

[4] Liu Ji-ping, Wang Li. The problems and countermeasures of the property management companies involved in the pre-existing. China Price, 2013(03) pp. 88-91.

[5] LUO Wei-ping. Some Issues in Early Stage Property Management. Journal of South-Central University for Nationalities (Humanities and Social Sciences) Vol.26 No.5 pp. 22-25.

[6] TIAN Jun, WU Jian-wei. The Problems and Counter- measures in the Taking and Acceptance of Real-estate Management Project. Hebei Software Institute. 2008(01) pp. 28-29.

[7] Liao Chuan-ming. The three elements of property management. Modern Property Management. 2007(02) pp. 11-13.

[8] Xie Shao-zhi. Property management and bidding practices book. Anhui Audiovisual Press, Hefei, 2005.

[9] $\mathrm{Xu} \mathrm{Bu}$-guo. The ponders to the series of our country preliminary estate managements. Administration and Law (Jilin Institute of Public Administration). 2006(03) pp. 10-12.

[10]Zhang Wen-bo. Service Dispute and Government Responsibilities in Earlier Property Management. Shanghai Urban Management, 2015(06) pp. 71-73 